\title{
ПОЯВА ВІДЕОФІЛЬМУ НА УКРАЇНСЬКОМУ ТЕЛЕБАЧЕННІ ТА ДІЯЛЬНІСТЬ ВІКТОРА КІСІНА. ІСТОРИЧНІ КОНТЕКСТИ
}

Поява відео на телебаченні спровокувала виникнення нового жанру 一 відеофільму. На українському телебаченні в 1970-1980 роках саме в межах иъього жанру проходили надзвичайно плідні й иікаві творчі експерименти і пошуки. Ці пошуки велися не лише у виражальній сфері, а й у методах і підходах до самого фільмовиробництва. В иеей час вибудовувалася принщипово інша конщепџія нового екранного видовища.

Ключові слова: відеофільм, телебачення, кіно, режисер, Віктор Кісін.

Появление видео на телевидении спровоцировало возникновение нового жанра - видеофильма. На украинском телевидении в 1970-1980 годах именно в пределах этого жанра происходили весьма плодотворные и интересные эксперименты и поиски. Эти поиски велись не только в выразительной сфере, а и в методах и подходах к саму фильмопроизводству. В это время выстраивалась принципиально другая кониепция нового экранного зрелищз.

Ключевые слова: видеофильм, телевидение, кино, режиссер, Виктор Кисисн.

The appearance of video on television provoked the emergence of a new genre - videofilm. There were many necessary and interesting searches in 1970-1980 in this genre on Ukrainian television. These searches were in the artistic and expressive sphere and in the methods and approaches of film production. A fundamentally different concept of a new screen spectacle was being built at this time.

Keywords: videofilm, television, cinema, director, Victor Kisisn.

Сьогодні повністю змінюється спосіб виробництва, як, власне, і сама природа телебачення і кіно. Новітні технології дедалі більше впливають на екранну видовищну творчість. Здавалося б, що у таких умовах, коли відео давно програло у двобої з електронними носіями, актуальність вивчення відеотворчості відійшла у минуле, та все ж існує необхідність звернення до епохи відео i до самого феномену відео як до передтечі усіх електронних, цифрових можливостей сучасного екрана. Слід зазначити, що саме поява відео стала першим кроком на шляху тих грандіозних перетворень, які сьогодні продовжують відбуватися із технологіями екранної творчості. Саме поява відео дала можливість визначити перспективи і пріоритетні напрями подальшого поступу і подальших пошуків.

Одним 3 мистецьких напрямів, який підтверджує актуальність розвідки у сфері відеотворчості є, зокрема, відео-арт. Щоправда, відео-арт від- носять більше до сфери так званого візуального та медіамистецтва, аніж до екранного мистецтва.

Існує погляд на відео навіть як на окремий культурний і мистецький феномен. Відповідно до цієї концепції поняття «відеофільму» цілком прив'язане до технічного носія, який забезпечує можливість перегляду. Таким чином, будь-який твір, що його $є$ можливість переглядати за допомогою відео, перетворюється на «відеотвір», будь-який фільм - на «відеофільм». Так, автори російського навчального посібника 2005 року видання «Нові аудіовізуальні комунікації» стверджують, що 3 появою побутового відео «з'явилася принципово нова форма спілкування аудиторії з екранним твором. Відеозаписи, як спеціально здійснені, так і такі, що являють собою відеоваріанти кінофільмів чи телевізійних програм, вилучаються з телевізійного мовлення. Споживач має справу з автономним твором, сприйняття якого він сам здатен контролювати, тобто зупиняти 
в будь-який момент, продовжувати далі, прискорювати, сповільнювати, декілька разів повторювати тощо. 3 цієї точки зору перегляд відеофільму ближче всього до читання книги...» [6, 207]. «Відтак очевидно, що відео не можна вважати ні в якій мірі складовою частиною ні телебачення як такого <...>, ні кіно...» $[6,207]$.

Та все ж слід віддати належне ролі відео в історичному й мистецькому розвитку телебачення. Отож звернення до відеотворчості в одній зі сфер його найяскравішого і найефективнішого функціонування — на телебаченні — дає змогу ширшого і глибшого вивчення насамперед історії самого телебачення. Історія українського телебачення саме й вимагає прискіпливого і ретельного дослідження. Відтак абсолютно не вивченим у цьому річищі залишається феномен відеофільму, зокрема і на українському телебаченні. Окремі розвідки присвячувалися телефільму (про український телефільм писали Юрій Косач, Нонна Капельгородська, Іван Мащенко та інші), але відеофільм на українському телебаченні досі не отримав належного висвітлення в контексті проблеми розвитку та пошуків у сфері екранної видовищної творчості XX століття. Порушував тему відеофільму іще у 1980-ті його започатковувач, практик і теоретик Віктор Кісін, про перші кроки українського документального відеофільму писав його практик, режисер Олексій Одинець, технічні особливості створення відеофільму розглядав Євген Палій. Та усі ці розвідки мають вигляд одиничних статей. Системного дослідження теми українського відеофільму так і не було здійснено.

Про появу відеофільму на українському телебаченні неможливо говорити без висвітлення праці на цій ниві Віктора Кісіна. Слід зауважити, що власне вся його діяльність: як практична, режисерська і педагогічна, так і теоретична, ще й досі потребує ретельного вивчення. Адже постать Віктора Кісіна - започатковувача кафедри режисури телебачення Київського інституту театрального мистецтва ім. І. К. Карпенка-Карого, режисера-експериментатора і педагога, — являє собою одну зі знакових постатей української режисерської педагогічної школи.

Відеофільм як новий жанр телевізійної творчості. Творчі та естетичні суперечності.

Палкий прихильник і популяризатор телебачення не як засобу масової культури, а, передусім, як мистецького видовища зі своїми, властивими лише йому особливостями, а відтак і можливостями, В. Кісін визначає відео на свій час як но- вий етап розвитку видовища. У своїй «загальній схемі розвитку видовищної культури» він виділяє відео окремим, останнім рядком, згадуючи його носії - відеокасети і відеодиски [3, 20]. Сьогодні відео посідає уже аж ніяк не останній рядок у розвитку видовищної культури загалом та екранної видовищної творчості зокрема. Однак те значення феномену відео, що його акцентував дослідник свого часу, не можна залишати недооціненим в історичному контексті та в контексті подальшого розвитку технологій і технік як інструментів екранної видовищної творчості.

Щодо самого відеофільму, як приватного випадку творчого впровадження відео у виробничий телевізійний процес, то Віктор Кісін був переконаний, що колись його історію писатимуть так, як писали історію кіно. Навіть сьогодні подібну історію можна написати лише про перші кроки і лише почасти. Почасти, адже можна сказати, що розвиток відео (як в професійних умовах телебачення, а згодом і кіно, так і для побутового ужитку) органічно продовжується цифровим форматом. А ця історія іще аж ніяк не завершена. Цифровий формат (хоча і не безуспішно) все ще знаходиться лише на шляху випробувань своїх сил і пошуків свого найоптимальнішого співіснування зокрема з усіма сферами екранної видовищної творчості.

Починаючи розмову про відео, В. Кісін зазначає, що з його появою з'явилася необхідність повної переоцінки специфіки кіно і телебачення. Такого очевидного бачення відмінностей природи цих різних за своєю суттю мистецтв, як раніше, уже не могло бути.

Передусім потребувало перегляду базове уявлення про телебачення як «дальнобачення». Чимдалі інтенсивніше порушувалося питання про його трансляційні можливості. Цю ситуацію зумовили спершу передача зображень, фіксованих на кіноплівку, яка все ж розглядалася первісно більше як додатковий привілей телевізійного ефіру, окрема його несамостійна опція, надалі - на спеціальну плівку, так би мовити «телевізійну». Таким чином, телебачення 3 появою відео мало б остаточно втратити свої специфічні самостійні властивості «дальнобачення». Воно б, можливо, і перетворилося на своєрідне кіно, тільки іншого, так би мовити, «домашнього», формату. Та до цього часу встигло сформувати цілу низку самостійних специфічних, притаманних саме йому засобів екранної виразності (програмність, інформаційність як базову ознаку, присутність диктора, ведучого, за яким іде глядач, співрозмовника - того, хто відкриває для глядача цю інформацію тощо), які 
і дали йому можливість, навіть 3 появою відео, продовжити своє самостійне мистецьке видовищне існування поруч 3 кінематографом та іншими видовищними мистецтвами. Та поява відео все ж спровокувала серйозне теоретичне переосмислення місця й ролі кіно і телебачення як самостійних екранних мистецьких видовищних форм.

В. Кісін чітко визначає стратегічні вузли розбіжностей кіно і телебачення як мистецтв іще до появи відео: «Сьогодні ми розрізняємо ці мистецтва не за способом фіксації, а за внутрікадровим змістом, за функціями і можливостями монтажу, за способами оперування часом і простором при відтворенні подій.» [2, 82].

Можливість трансляції кінозображення впродовж розвитку телебачення породила появу нових жанрів на його екрані. Серед цих форм з'явився i телевізійний фільм. Саме поява телевізійного фільму зробила надзвичайно непевною і хиткою межу поділу кінематографічної і телевізійної специфіки у подібних жанрових формах.

Первісно технологія виробництва телевізійного фільму навіть особливо не відрізнялася від технології кіновиробництва, адже в обох випадках зображення фіксувалося на кіноплівці з одною умовою: кінофільми були розраховані на показ у кінотеатрах (на великому екрані), а телевізійні фільми - для трансляції по телебаченню (на малому екрані). Така цільова орієнтація, за великим рахунком, так і не стала визначальною для специфічного визначення та розрізнення жанрів, отож сформувалося стійке уявлення, що телебачення потребує власного виробництва фільмів для забезпечення своїх особистих потреб. Ситуація з жанровою класифікацією ще більш ускладнилася з появою відео. Точніше, з тим етапом його розвитку, коли відео уможливило не лише елементарну фіксацію зображення, а й забезпечило здійснення повного циклу виробництва і навіть запропонувало інструменти творчості, якими на той час не володів кінематограф або володів в умовах достатньо складного технологічного виробничого процесу (це різноманітні спецефекти, результат з якими досягався значно простіше і менш затратно аніж у кіно; можливості кольорової і тональної загальної корекції зображення, що давали чи не моментальний результат, і можливість швидкої зміни; використання шрифту і графіки також було значно простішим і менш затратним, аніж у кіно тощо).

Галина Шергова, тоді член сценарно-редакційної колегії Московської студії художніх телефільмів творчого об'єднання «Екран», спробувала дещо узагальнити новітні можливості телебачен- ня із появою відео і навіть вивести їх естетичні засади:

«1. Художничеське (наголошую - художничеське!) використання спецефектів дає багатозвучний спектр на пластичній палітрі екрана в композиції кадру, у монтажі, у зображальних акцентах.

2. Відеотехніка дає змогу вести довгу, ненав'язливу (не як під оком кінокамери!) бесіду 3 героєм. Це дає можливість добитися найбільш повного духовного розкриття людини у кадрі.

3. 3'явилась можливість не контратипирувати стару плівку, що зберігає відчуття свіжості минулих подій.

4. Відеотехніка принесла також природність поєднання різноманітних телевізійних жанрів у одному фільмі, забезпечуючи органічне поєднання ігрового і документального мистецтва» [11, 121-122].

I от 3 такими, а надалі й 3 іншими, більшими i більшими новими можливостями почали експериментувати телевізійники, не лише режисери, а передусім технічні працівники.

Іще наприкінці 70-х років XX ст. московський режисер I. Романовський стверджував, що «уже сьогодні відеотехніка впливає на формування сценарних і режисерських задумів, які можуть бути втілені тільки при використанні іiі багатих можливостей. Але скільки ще потрібно осягнути, вивчити, сформувати!» $[10,56]$. А інший практик телебачення, А. Лисенко, тоді редактор-консультант Головної редакції програм для молоді Центрального телебачення, відзначав: «при відеозаписові кількість записаного матеріалу переходить в якість, вірніше, дає можливість створити цю нову якість» $[5,63]$. Ідеться передусім про технічні можливості фіксації великої кількості матеріалу, котра потім отримує у подальшому процесі підготовки твору свою якісну характерність.

Полем для творчих експериментів і пошуків із застосування нової відеотехніки і технології виробництва могли стати телевізійні художні форми (рідше інформаційні). Саме на таких засадах В. Кісін звертається до жанру відеофільму і розпочинає його теоретичне і практичне осмислення в реаліях українського телевізійного виробництва. Він прагне розширити поле експерименту на великі форми, повнометражні проєкти. Він бачить величезний потенціал таких експериментів в умовах розвитку українського телебачення.

Олексій Одинець зауважує, що спершу В. Кісін пропонував до ужитку термін «електронний фільм». «Він вважав, що наявний термін <..> 
прив' язаний до відеомагнітофонної стрічки-носія. Термін своїм походженням зобов'язаний технології фіксації, і замість нього пропонувалася назва “електронний фільм”, яка походила від того, що зображення і звук створюються і передаються за допомогою електронної апаратури.» $[7,111]$. Та, як видно, термін, запропонований українським дослідником, не прижився, адже широкоуживаним уже було поняття «відеофільм».

«Відеофільм» В. Кісін зрештою визначає як «сплав можливостей та естетичних якостей кіно i телебачення» $[2,82]$. Зникнення кордонів між кіно і телебаченням, що його натхненно передбачає автор у контексті реалізації цього нового жанру творчості, з часом справді відбувається і навіть призводить до повного взаємопроникнення.

«Збереження реальності, безперервності простору і часу, безперервності розвитку подій - ocновна видова особливість телебачення. Покадрова зйомка, монтажне "конструювання" подій за рахунок відчутних змін просторових і часових “параметрів" відзнятого матеріалу — все це створює ту особливу динаміку та образну структуру кіно, яку сучасний глядач легко відрізняє від неквапливої достовірності телебачення.» $[2,82]$. Дивовижно, але ті характеристики екранних мистецтв, що їх наводить В. Кісін, так, як вони виглядають на 1983 рік, сьогодні не надто виражають художні особливості й відмінності кіно і телебачення. I для кіно, і для телебачення сьогодні можна залучити як одне, так і інше визначення. Імовірно, це і $є$ результатом того взаємного впливу, зникнення кордонів і розмежувань, що відчувалося уже у 80-ті роки XX століття.

Визначення «відеофільму» В. Кісіна зі свого боку підтримує старший інженер Київського республіканського телецентру Свген Палій, який оперує, як і належить інженерові, більш технічною термінологією. «Відеофільм - це телевізійний твір, народжений засобами телевізійної техніки, який поєднує елементи телевізійного театру, телевізійного кінематографа і прямої передачі». [8, 96]. Надалі Є. Палій відзначає характерні риси відеофільму у порівнянні з кінофільмом: «Очевидна різниця між кіно- і відеофільмом полягає в різній технології їх виробництва, що зумовлена використанням принципово різної апаратури.» $[8,96]$.

Дослідник телевізійного фільму, український радянський мистецтвознавець Юрій Косач, фактично підтвердив самостійне існування жанру відеофільму як особливого і самодостатнього. Він у 1984 році зазначав: «Вже перші успіхи відеофільму показали, що він здатний оволодіти цілим рядом виражальних особливостей, не властивих кінофільму, знятому на плівці, що відеозапис не тільки технічний засіб, а головне - нова естетична форма, яка відкриває небачені обрії для ще тіснішого зв'язку телевізійного кіно з усіма іншими формами і жанрами телебачення.» [4, 32-33].

В. Кісін, між тим, відзначає надзвичайно важливу особливість відеофільму (яку, зрештою, можна віднести не лише до цього жанру, а й в цілому до усієї сфери відеотворчості), що принципово відрізняла його від кіно: «Розвиток телемистецтва, а відеофільму - особливо, залежить від розвитку техніки, опанування іiі нових можливостей, перетворення іiї у виражальні засоби. Ця ситуація поки що унікальна в історії мистецтв, навіть якщо враховувати досвід кіно, де з рівня 20-х років усе було навпаки: розвиток кіномистецтва вимагав удосконалення кінотехніки. Тому кожний новий крок у напрямку відеофільму ми повинні розглядати слідом за кроками техніки відеозапису і телезйомки.» $[2,83]$. Справді, нові й нові технічні можливості, раніше навіть і не мислимі, досі залишаються потужним стимулятором уяви митців екрана (не лише режисерів, а й операторів, монтажерів та інших). Спершу елементарні ефекти, а на сьогодні вже і складні перетворення і трансформації, що їх може зазнавати й фіксоване зображення (або уже навіть і зображення у процесі фіксаціi) розширюють творче поле експерименту фактично до безмежності.

\section{Історія становлення жанру відеофільму на} українському телебаченні.

Говорячи про особливість розвитку українського відеофільму, В. Кісін виходить з положення, що українські, і зокрема київські телемитці, вимушені були слідувати за митцями російськими, з Центрального телебачення, яке тривалий час набагато випереджало розвиток республіканських телевізійних студій за технічними, а відтак і за творчими показниками.

Так, якщо перший запис Центрального телебачення 3 передачею його в ефір в Радянському союзі відбувся 20 лютого 1960 року з відеомагнітофона «Кадр-1», спроєктованого і виготовленого в Москві, то перший відеозапис на екранах українського телебачення з'явився лише через чотири роки (!), в березні 1964 року з одного з перших екземплярів відеомагнітофона КМЗІ ленінградського об'єднання ЛОМО. Відомо, що керував роботою інженер С. Копанський. Назва ж і точна дата цього відеозапису не встановлені. Першими програмами, котрі передавалися в ефір, були футбольні матчі та театральні вистави. 
На ранніх етапах появи відеозапису на телебаченні, як зазначає Василь Вітер, «про монтаж можна було говорити тільки як про монтаж 3 кількох камер, що транслювали події наживо під час зйомок за пультом ПТС (пересувної телевізійної станції). Записували це на велетенські магнітофони висотою в людський зріст і на такі ж велетенські відеобобіни, розміром як колесо легкового автомобіля. Хронометраж їхній був 30 хв. або 60 хв. на плівці ТЛЦ.

Монтажна можливість склейки відзнятого матеріалу існувала, але тільки для інженерів і для технічних потреб (підклеїти технічний початок запису і його закінчення). Одна така склейка тривала до 10 хвилин - так було прописано в інструкціях. Для порівняння: склейка на кіноплівці відбувалась за 15-20 секунд.» [1, 32-33].

Самому Вікторові Кісіну в 1964 році пощастило бути режисером однієї з перших постановочних телевізійних програм, що знімалася на відео, - передачі про Л. Українку. Провідні діячі мистецтв з фойє театру ім. Л. Українки розповідали про українську поетесу, ювілей якої якраз відзначався. «Камери пересувної телестанції через "малий ефір" посилали зображення на телецентр, де два магнітофони КМЗІ (кожен важив майже тонну) записали на величезні рулони цю передачу. А наступного вечора $з$ цих солідних апаратів запис було передано у Москву на антени ЦТ.» $[2,84]$.

Тоді працювали ще на апаратурі «першого покоління», яке давало чорно-біле зображення. Хронометраж становив не більше години без можливості монтажу. Зупинка або якась невправність коштували дуже дорого: потрібно було весь запис починати з самого початку. Як згадує В. Кісін, на 56 хвилині актор переплутав текст і довелося починати все знову. Це негативно відобразилося на загальній якості програми: вона втратила «привабливість першого імпровізаційного дихання».

«Друге покоління» апаратури уже значно розширювало технічний, а відтак і творчий потенціал відеозапису на телебаченні: дозволяло кольорове відтворення, підвищувало якість передачі зображення, відчутно збільшувало можливості управління його характером, ввело в професійний ужиток рухливі камери 3 трансфокаторами, а також відеомагнітофони «Електрон-2» та «Кадр-2» 3 можливістю електронного монтажу відеозапису. Все це зрештою уможливило виникнення нового напряму телевізійної творчості - відеофільму.

Відеомагнітофон «Електрон-2» з'явився на українському телебаченні в листопаді 1968 року. «Ці апарати дозволяли вести запис із зупинками зйомки: і в режимі продовження запису, і в режимі вставки нового фрагмента в готовий запис. Тепер режисери телебачення могли знімати за кінотехнологією: кожен кадр окремо і будь-якої довжини; могли ретельніше працювати над деталями зображення і звуку. Це був важливий етап в опануванні телебаченням досягнень кінозйомочного процесу, зрештою - кіноестетики.» [2, 85-86]. Зображення, однак, продовжувало на цей період залишатися чорно-білим.

Історія становлення відеофільму була б неповною без окремої згадки про технічних працівників - інженерів, які працювали над удосконаленням устаткування, що надходило з Москви для роботи. Так, протягом року апарати «Електрон-2», були «реконструйовані» (імовірно, зазнали значних технічних переробок), за свідченням В.Б. Кісіна, інженерами Київського телецентру А. Іванченком та Ю. Сервінським спільно з СКБ ЛОМО для кольорового відеозапису. Завдяки цим зусиллям перший кольоровий запис вийшов в ефір у жовтні 1969 року, що було на два роки (!) пізніше, ніж на Центральному телебаченні, та на чотири роки (!) раніше, ніж студія була забезпечена 3 Москви серійними апаратами для кольорового відеозапису. До слова, першу кольорову програму було записано і відтворено на лабораторних блоках, які надалі запустили у серійне виробництво, а відеомагнітофони «Електрон» на усіх телестудіях СРСР надалі стали кольоровими.

Старший інженер Київського республіканського телецентру Євген Палій взагалі зауважує, що творчий процес створення відеофільму «відрізняється від “оптичного” кіно перш за все прямою участю відеоінженерів в усіх творчих “операціях", починаючи із задуму» $[8,96]$. Він, зокрема, зазначає, що з появою відеозапису творча група сконцентрувала свою увагу на нових виражальних засобах, закладених в техніці. І дедалі частіше режисери, оператори, художники почали звертатися до інженерів по консультації про творчі можливості апаратури.

В. Кісін, із належним йому захопленням, натхненно описує творчу атмосферу, в якій здійснювався на київському телебаченні експеримент із впровадження відео у телевізійну практику. «Всі важливі кроки в розвитку відеофільму на УТ були б просто неможливі, якби не постійна підтримка 3 боку інженерів, ініціатив режисерів та операторів по новому використанню техніки в творчому процесі. Талановиті інженери... були справжніми співавторами кращих передач УТ, "витискували" з техніки такі можливості, які зго- 
дом ставали нормою лише для апаратури наступного покоління.» $[2,86]$. Ініціатором, запалювачем такого колективного робочого натхнення, власне, був в тому числі й сам Віктор Кісін.

Пошуки зображальної мови телебачення (зокрема, у форматі відео), відмінної від мови кіно, зрозуміло, були найбільш продуктивними при створенні художньо-постановочних програм. Відтак тривалий час розвиток відеофільму на українському телебаченні пов'язувався напряму 3 телевиставами і музичними програмами. Так, першим кольоровим записом стала вистава лялькового театру «Чарівна калоша» телережисера С. Челока і оператора В. Юрченка.

У 1972 році передачею «Дівочі мрії» (режисер Ю. Баранович, оператор Ю. Бордаков, художник А. Перепелиця, відеоінженер С. Федоров) було зроблено спробу створити своєрідний оригінальний телевізійний жанр. Українська артистка Ніна Матвієнко та ансамбль «Мрія» виконували низку театралізованих пісень. «Динаміка передачі, побудована на контрастах і багатстві зорових вражень, точний розрахунок ритму у монтажних зіткненнях, широке використання напливів, рірпроекцій, комбіновних кадрів - багато було в цій програмі від відеофільму (тоді, до речі, це поняття ще не було поширеним).» $[2,86]$. «Дівочі мрії» кілька разів транслювалися по українському телебаченню і двічі - по центральному. Такі експерименти були рідкісними також і на ЦТ.

Реалізація подібних проєктів могла відбуватися на той час лише за умов монтажу під час самої зйомки. Зйомка ж, хоч і могла проводитись із зупинками, мала вестися лише в порядку розвитку сюжету і без дублів. Отже, ніяких технічних можливостей здійснення монтажу після зйомок із творчим переосмисленням та оцінкою відзнятого матеріалу до того часу в режисерському арсеналі так і не було.

У травні-червні 1974 року після появи апаратної 3 трьома відеомагнітофонами «Кадр-3» (в 1973 році) з можливостями перезапису і вільного монтажу зображення та на базі кольорової студії була здійснена спроба зйомки та монтажу телевистави «за повною технологією відеофільму» (за виразом В. Кісіна). Було обрано п’єсу «Весняний день тридцятого квітня» про події під час штурму Берліна в 1945 році. Режисером став Віктор Кісін. Знімальна група: художник Е. Колесов, оператор П. Черняхівський, асистент режисера Н. Фролова, інженери відеозапису О. Венгрін, П. Глузд, М. Омельчук.

Про один зі своїх власних кроків «на шляху до відеофільму» оповів режисер українського телебачення Олексій Одинець. Свій фільм 1974 року за повістю Володимира Дрозда «Люди на землі» (оператор П. Черняхівський) він скромно визначає як телевиставу. Ця постановка важлива тим, що здійснена вона була за межами студії, i, об' єктивно кажучи, принаймні окремі елементи відеофільму були наявні й у ній.

Автори вирішили поєднати студійні зйомки 3 кадрами сцен, відзнятими у реальних обставинах за допомогою ПТС. Практично, як зазначає О. Одинець, це була перша подібна спроба на Киїському телебаченні. Таких сцен було дві: одну знімали на автобазі у Києві, другу - на тваринницькій фермі села Халеп’я. «Цього разу ми ще більше відійшли від канонів кіновиробництва, відмовившись зовсім від дублів сцен і подальшого озвучення кадрів, навіть відзнятих в умовах колгоспної ферми і автобази засобами ПТС. Технологія телебачення давала можливість іти таким шляхом: записана сцена переглядалася на місці і ніякої “страховки” не вимагала. Звук, записаний в умовах зйомок на натурі, цілком задовольняв i звукорежисера $\langle\ldots\rangle$, i режисера-постановника.» [7, 105-106]. Зйомки проводилися поепізодно: монтажною одиницею був не окремий кадр, як у кіно, а подія, сцена, епізод. Таким чином, за багатьма показниками (насамперед технічними): зйомки телевізійними засобами, електронний монтаж, запис на відеоплівку первинного і кінцевого продукту — цей фільм наближається за способом і технікою виробництва до відеофільму.

У наступній телевиставі О. Одинця за романом Миколи Олійника «Зерна» творча група уже сміливіше планувала позастудійні зйомки із задіянням ПТС у природних умовах. Наступним кроком на шляху до відеофільму, як відзначає сам О. Одинець, було більше подрібнення монтажної одиниці уже від епізоду і сцени до окремої події. Та кадр як монтажна одиниця досі іще не був осягнений.

Монтаж телевистави здійснювався у монтажній апаратній на відеомагнітофоні «Кадр-ЗП», керування яким могло здійснюватися через пульт управління. Та і режисери, і відеоінженери на той час іще не звикли до нововведення і «не завжди користувалися автоматикою».

Отже, складнощів на шляху до повноцінного відеофільму було надзвичайно багато: недостатньо розвинута техніка відеозапису, мала кількість магнітофонів, недостатня кількість студійних площ. Набутий в процесі роботи досвід можна було використовувати винятково у виробництві складних постановочних програм, але для щоденного застосування в умовах тогочасного телеви- 
робництва цей процес був занадто трудомістким і складним.

Таким чином, виробництво відеофільмів за технічних обставин довелося відкласти і поновилося воно на українському телебаченні лише з 1978 року, з початком роботи монтажної апаратної з трьома «Кадрами-ЗП», що забезпечували напівавтоматичний монтаж та зі збільшенням кількостей студій $з$ кольоровою апаратурою.

Важливі експерименти на шляху до відеофільму тривали також і в сфері телевізійної документалістики та публіцистики. Тут засвоєння специфіки відеовиробництва було не таким затратним. Одним з перших проєктів на цьому шляху був цикл «Найдорожче» 1976 року Олексія Одинця. Сам О. Одинець і ці свої фільми не вважає повноцінними відеофільмами. Та «ці програми, незважаючи на наявність готових відзнятих i змонтованих кінофрагментів, що демонструвалися учасникам передачі в студії і ставали предметом обговорення, своєю технологією виробництва передбачали обов' язковий відеомонтаж, результатом якого була готова програма. Кінофрагменти практично завжди записувалися одночасно зі студійною частиною.» $[7,107]$. Тут також велася поепізодна зйомка. Одиницею монтажної побудови була подія, що відбувалася у студії.

У створеному в 1978 році відеофільмі «Автограф. Алла Пугачова» (режисер Ю. Баранович, оператор В. Юрченко) було вперше застосовано метод тривалого багатокамерного спостереження та накопичення матеріалу. Робота над драматургією проводилася вже після зйомок. Успіх фільму став важливим стимулом для подальших творчих пошуків. Також з цього проєкту започаткувалася тісна співпраця у роботі над відеофільмом творчих та інженерних працівників, починаючи з етапу задуму фільму.

В. Кісін свідчить, що протягом року сформувалася група ентузіастів, яка створила низку цікавих проєктів. «Кожний відчував себе співавтором фільму, кожний робив внесок і в драматургію, i в зображальне рішення, і в режисуру, і в технічні процеси, отже фільм ставав своєрідним сплавом цих зусиль. Душею групи були відеоінженер Сергій Федоров та художник Едуард Колесов, вони і раніше активно працювали над створенням відеофільмів. У творчому контакті з ними були В. Шульгін, оператори Ю. Бордаков, О. Сульдін, редактор М. Амосов. Інженери А. Пичерога, Ю. Матяш, Є. Палій. Можна сміливо твердити, що такий тісний неформальний контакт творчих та інженерних працівників, який в Києві вже став доброю традицією, — явище нове в історії радянського телебачення.» $[2,88]$.

Визначними кроками для розвитку українського відеофільму стали перший документально-публіцистичний відеофільм 1978 року «Вагомий колос України» (режисер О. Одинець, оператор В. Канюка, інженери О. Венгрін та А. Пичерога), «Міфи і дійсність» 1980 року виробництва тієї само знімальної групи, «Кобза» (режисер В. Шульгін), «Справа про час» 1980 року.

Технологія виробництва цих фільмів, як свідчить О. Одинець, мало чим відрізнялася від попереднього. Тут так само поєднувалися кінозйомки камерою «Еклер» зі зйомками ПТС на полях та інших угіддях (у фільмі «Вагомий колос України» О. Одинця). Хоча у Москві на ЦТ у цей час уже використовували портативну телекамеру ТЖК (тележурналістський комплекс) 3 ранцевим або пересувним, на візку, відеомагнітофоном, який працював уже на плівці БЦН, значно вужчій від ТЛЦ і давав режисерові значно ширші можливості у порівнянні з монтажем на широкоплівочних відеомагнітофонах «Кадр-ЗП». «У нас такої техніки ще не було. Ми були змушені поєднувати кіно і телетехнології. Для збереження якості оберненої кіноплівки, яка після декількох прогонів (не кажучи вже про проєктор, навіть на монтажному столі) потребувала реставрації, ми <...> процес кіномонтажу зводили до мінімуму, лише "підбиралися” синхрони (розмови людей в кадрі), і кіноматеріал переганявся на відеоплівку, після чого й відбувався його остаточний монтаж.» $[7,108]$.

У фільмі «Міфи і дійсність» 1980 року (режисер О. Одинець, автор сценарію В. Пасак) «Творча група з ведучим телеінженером А. Печерогою зуміла експресивно поєднати у процесі відеомонтажу за допомогою спецефектів і поліекрана тогочасну зарубіжну кіно- і відеохроніку з власними відеоматеріалами, відзнятими ще за допомогою тої самої кінокамери “Еклер" (кінооператор В. Канюка). Результатом такої роботи став гострий фільм-памфлет.» [7, 109-110]. Саме цей свій фільм О. Одинець вважає першим повноцінним відеофільмом у своій режисерській практиці, адже методом кіновиробництва таку стрічку створити було б неможливо.

У квітні 1981 року вперше в системі радянського телебачення було створено спеціальний підрозділ - відділ з виробництва відеофільмів. Упродовж того ж 1981 року було випущено два художніх і один музичний відеофільм. Паралельно на студії «Укртелефільм» велася робота відеоспособом над повнометражним фільмом-балетом. 
У 1982 році було завершено будівництво нового павільйону 3 сучасною відеотехнікою, де було вирішено розгорнути виробництво відеофільмів. Згодом павільйон обладнали сучасною телевізійною технікою.

Як згадує В. Вітер, «на початку 80-х на українському телебаченні за ініціативи Віктора Борисовича було створено відділ із виробництва відеофільмів, а згодом - об'єднання в структурі студії “Укртелефільм". У ньому працювали учні В. Кісіна — молоді режисери, перші випускники заснованої ним кафедри телевізійної режисури. Вони розуміли специфіку фільмовиробництва в умовах телебачення.» $[1,33]$.

Таким чином В. Кісін доклав чимало зусиль також і для збагачення телебачення творчими кадрами, заснувавши разом з В. Чубасовим кафедру режисури телебачення при тодішньому Київському державному інституті театрального мистецтва ім. І.К. Карпенка-Карого, очоливши іiі і продовжуючи працювати як майстер курсу телевізійних режисерів. Так, уже в 1981 році режисерами двох тридцятихвилинних відеофільмів за новелами Євгена Гуцала виступили випускники інституту B. Вiтер та I. Кобрін, уже над зйомками багатьох відеофільмів працював випускник телеоператорського факультету Ю. Бордаков та інші.

Зрештою, В. Кісін на 1983 рік з усією відповідальністю стверджував: «Виробництво відеофільмів у Києві подолало важливий рубіж. Якщо раніше воно відбувалося від нагоди до нагоди і багато в чому залежало від ентузіастів, які в основному робили планові передачі, то тепер організовано групу, для якої відеофільм - постійна турбота, професія. До цієї групи з розширенням виробництва (а таке розширення вже заплановане) зможуть увійти і досвідчені кадри телебачення, і перспективна молодь. Тепер є можливість постійно розвивати технологію відеофільму, комплексно вирішувати кадрові та технологічні проблеми.» [2, 91].

О. Одинець, проте, звертає увагу на особливість роботи об'єднання «Відеофільм» на студії «Укртелефільм»: «За роки свого існування об'єднання випустило багато різнопланової продукції, але, на жаль, електронний спосіб виробництва телефільмів чомусь не став на "Укртелефільмі" домінантним, попри зусилля молодих режисерів, зокрема I. Кобрина і В. Вітра, які увійшли до складу цього об'єднання.» $[7,116]$.

Творчі контексти жанру відеофільму на етапі становлення.

Поява відео як технічної можливості значно розширила потенційне поле творчості перед мит- цями різних напрямів. Особливо В. Кісіна у цьому контексті цікавило зображальне вирішення екранного твору. Робочий арсенал оператора і художника у процесі розвитку техніки збагатився новими інструментами.

«При телезйомці оператор бачить те ж саме, що побачить і глядач. Відразу ж після зйомки дубля вся група може оцінити результат. Через це телеоператор працює значно сміливіше, він може собі дозволити таку міру імпровізації, на яку кінооператор ніколи не зважиться, оскільки результат 3'ясується лише через кілька днів. Коли зйомку, як правило, вже не можна повторити. Все це створює принципово новий психологічний контакт 3 апаратурою, зображенням, з акторами i, нарешті, з глядачем. Можна сказати, що ми ще не навчилися перетворювати переваги такої зйомки на нові виражальні засоби, рідко користуємося безпосередністю імпровізаційної телекамери, монтажем, що твориться під час зйомки, можливостями тієї, я б сказав, психологічно об’ємної зйомки, яка здатна утворювати особливий ефект співучасті глядача в екранній дії не “я дивлюся", а “я знімаю".» $[2,93]$.

Сьогодні такі можливості знімальної техніки стали робочою реальністю не лише в умовах телебачення (щоправда, зовсім не в усіх його формах і жанрах), а й у кіно. У наведеній цитаті хочеться звернути увагу на розуміння теоретиком і практиком самої суті процесу і творчих можливостей, які відкриваються. Такі поняття, як «психологічний контакт з апаратурою, зображенням, з акторами і глядачем», «безпосередність імпровізаційної телекамери», «психологічно об'ємна зйомка», ефект співучасті глядача (за аналогією з театром і кіно), ефекти «я дивлюся» і «я знімаю» залишилися авторськими поняттями в теорії В. Кісіна, які не втрачають, одначе, своєї актуальності навіть сьогодні. Усі ці феномени, про які згадує практик, а вже потім дослідник В. Кісін, варті ретельного вивчення уже у контексті сучасної екранної творчості та її подальших шляхів розвитку й перспектив. Імовірно, окремі $з$ них уже досліджувалися (як, наприклад, ефекти «я дивлюся» $\mathrm{i}$ «я знімаю», зокрема, в контексті поняття суб' єктивної камери) в дещо іншій термінологічній інтерпретації. Точність же визначення, запропонованого В. Кісіним з точки зору передусім практичної режисури, все ж робить ці поняття своєрідними термінами, і розкриває дещо інші грані їх можливостей. Вживання, наприклад, тих же термінів «ефекти “я дивлюся” і “я знімаю”» порушують зовсім інше коло проблем з точки зору естетики екранного, 
знімального, а надалі й інтерпретованого засобами монтажу, зображення.

Стрімкий і складний розвиток відеотехніки й технології виробництва зумовив на телебаченні нові умови взаємодії творчих і технічних працівників. Передові режисери постійно намагалися підвищувати свої знання в галузі телетехніки, проте арсенал новітніх засобів настільки стрімко розвивався, що без глибокого інженерного розуміння структурних і функціональних особливостей апаратури нею неможливо було оволодіти. Телеоператор за аналогією з кінооператором уже не міг брати на себе основні функції інженерного мислення, оскільки складність телеапаратури була уже на кілька порядків вища, ніж кіноапаратури, як зазначає інженер українського телебачення $Є$. Палій. Усі перелічені проблеми зрештою знайшли своє практичне вирішення: «Повна i досконала режисерська розробка літературного сценарію на телебаченні сьогодні неможлива без участі технічного персоналу, який обслуговує телевізійну техніку.» $[8,97]$. Таким чином, відеоінженери повністю влилися у творчий процес творення відеофільму на телебаченні.

Досвід експериментальних творчих груп, за твердженням Є. Палія, добре зарекомендував себе при створенні не тільки відеофільмів, а й складних телевізійних програм. Креативний підхід до розробки кожного окремого проєкту із залученням до творчої співпраці усіх без винятку фахівців телебачення загалом стали ознаками розвитку телебачення періоду 1970-1980 років. Відео у цьому процесі відігравало роль стимулюючо-подразнювального фактора. Освоєння його інструментарію провокувало творче натхнення і пошук нових виражальних можливостей екранної творчості. Як зазначав у 1983 році Є. Палій: «Становлення відеофільму спочатку йшло по шляху запозичення методів кіно та ефірного телебачення. Зараз же ведуться інтенсивні пошуки власної мови, стилістики відеофільму, однією з характерних особливостей якого $є$ можливість необмежено вільної екранної інтерпретації художнього образу і сюжетної побудови.» $[8,99]$.

В. Кісін також підіймає важливе питання про появу своєрідної професії художника відеофільму. Дослідник уже в той час розумів особливі специфічні художні можливості відео як зображального мистецтва, бачив його перспективи у напрямі, який на сьогодні розвинувся навіть уже й у такий самостійний вид творчості як відео-арт. Його спостереження, однак, стосуються питання органічної взаємодії результатів роботи художника з фак- турою відеоматеріалу, пропонованою оператором і можливостями знімальної техніки. «Очевидно, правомірно говорити про електронну графіку, електронний живопис, електронну сценографію. Словом, про новий вид образотворчої виразності, яка реалізується в матеріалі телезображення, яким легко керувати, яке має насичені і прозорі кольори; зображення, яке здатне реальне середовище перетворити у графічне умовне тло і навіть у динамічну кольорову музику. Тут деталь, світловий блік, предмет реквізиту, попадання у камеру прямого променя світла виконують активні образотворчі функції. Ось чому таке важливе уміння Е. Колесова контактувати з інженерами та операторами, створюючи на екрані зображення, характерне саме для даного матеріалу.» $[2,92]$.

Подібні та інші пошуки й експерименти з особливостями й фактурою екранного зображення Biктор Кісін зауважував та відзначав і в інших українських відеофільмах. Зокрема, він звертає увагу на епізод з фільму «Кобза» режисера В. Шульгіна, де в стрічку вмонтовано кілька епізодів з анімаційного фільму «Як козаки по сіль ходили». «Але це не просто кіноцитати. Наприклад, воли, що везуть гарбу 3 мішками солі, на телеекрані <...> затанцювали під музику “Кобзи”: кадри мультфільму пропустили через апаратуру, що дозволяє багатократно повторювати рух, змінювати його темп і напрямок. Аналогічні операції було здійснено і з відзнятими у студії мізансценами акторів. Ця знахідка, застосована групою вперше, 一 яскравий приклад післязйомочного втручання у внутрікадровий зміст, що < ..> ставить режисера в позицію мультиплікатора, який не просто дає репродукцію руху, що відбувається перед камерою, а може заново відтворити зафіксований на стрічці рух, користуючись магічною владою відеотехніки над відзнятим матеріалом.» [2, 89-90].

Таким чином, у своїх творчих режисерських прагненнях Віктор Кісін ішов далі можливостей, що їх давала змогу використовувати техніка кіно на той час - робота 3 відзнятим на плівку матеріалом засобом монтажної компіляції. Він бачив новітні можливості відео як екранного мистецтва у повному перетворенні відзнятого матеріалу. Це мало відбуватися не лише на рівні монтажу, а й на рівні докорінної зміни зафіксованого на електронний носій зображення (корекція кольору, руху, темпу, напряму тощо). Чим більша кількість складових зображення (й не лише зображення) могла зазнати перетворень, тим цікавішим був експеримент, тим неочікуванішим і фантастичнішим міг бути потенційний результат. 
Своє прагнення творчого експерименту із взаємодії різних фактур екранного зображення В. Кісін як режисер максимально можливо реалізував у фільмі 1983 року «Останній засіб королів». Автори фільму свідомо обрали шлях творчого пошуку. Цей 4-серійний серіал значно відходить від традицій телевізійного театру, з одного боку, з іншого - він також і не $\epsilon$ спробою стати аналогом кінофільму.

Фільм «Останній засіб королів» $€$ повноцінним новим продуктом свого часу. Автори працювали 3 усвідомленням того, що створюють саме відеофільм. Вони, отже, намагались органічно задіяти усі новітні специфічні технічні можливості суто відео задля найвиразнішого втілення на екрані загального перебігу подій (рирпроєкцію як із шматками відзнятого відео, так і з графікою, можливості телевізійного монтажу, багатокамерну зйомку тощо). «Кісін запропонував принципово нову естетику у фільмовиробництві. Вона виходить із самої природи утворення відеозображення та його потенційних можливостей, поелементного розчленування цього зображення і продовження обробки окремих елементів цього зображення, додаючи йому нових якостей, а часом і нового смислу.» $[1,33]$.

Перед знімальною групою, судячи 3 усього, стояло достатньо складне завдання: створити уявлення американської дійсності (в тому числі 3 інтер'єрами Білого дому, кабінетів ЦРУ, американського телецентру тощо). Це завдання автори фільму успішно вирішили, в тому числі також і за допомогою саме технічних можливостей відео, зокрема, із застосуванням рирпроєкції в умовах відеовиробництва. «Багато режисерів використовували цей прийом (часто виправдано, іноді зовсім недоречно), але до «Останнього доказу королів» не було жодного відеофільму чи телевистави, у яких рирпроекція використовувалася б і як основний художній прийом, і як основний виражальний засіб.» [7, 117].

Загалом зображальний ряд серіалу — принципово витриманий у телевізійній естетиці 1980х з їі жорсткою насиченістю кольорів і чітким контуром картинки.

Впродовж розгортання сюжету використані навіть специфічні, так би мовити, «чорнові» можливості відео: в кадрі показано перемотку, стоп-кадри, пришвидшення і уповільнення зображення. Така демонстрація усіх можливих режимів роботи відео з'являється цілком органічно, у зв'язку з нагальною необхідністю оповіді. Сам цей прийом вільного поводження з відео у відеотворі створює ефект імпровізаційності під час зйомки.
У фільмі «Останній засіб королів» «Віктор Кісін активно застосовує нові прийоми монтажу. У нього звична кіношна "вісімка" перетворюється на поліекран. I два персонажі, що ведуть діалог між собою, існують для глядача одночасно, і глядач має можливість сприймати дію та реакцію на цю дію одномоментно двох і більше персонажів.

Активно застосовуються хронікально-документальні матеріали із одночасним коментарем автора-журналіста (в структуру фільму було введено відомого тоді на Центральному телебаченні журналіста-міжнародника Володимира Дунаєва), зі стрімким переходом до чисто ігрових епізодів (актори А. Роговцева, Г. Дрозд, О. Філіпенко та ін.). А потім додається музика - не як емоційна підтримка, а як активний натиск на глядача. Фактично це зонг із обов'язковим смисловим навантаженням. Отже, за задумом режисера, відбувається і штурм свідомості глядача.» $[1,33]$.

Таким чином, у фільмі «Останній засіб королів» Віктор Кісін продемонстрував навіть далеко не весь, але надзвичайно потужний і різноплановий спектр можливостей, що його відкривало відео для режисерської екранної творчості. I на прикладі свого фільму запропонував режисерам скористатися цим засобом, спонукаючи і молодих митців до творчого пошуку й експерименту на цій ниві.

3 іншого боку, відео не обмежувало сферу свого впливу виключно у межах телевізійної творчості. Його можна розглядати і ширше: також і як впливове загальнокультурне явище. Російський дослідник Кирил Разлогов в 1987 році зауважував, що феномен відео має надзвичайно потужний вплив також і на інші екранні видовища. «...Виникла інша тенденція - все більшого використання відеотехніки в ході створення кінофільму. Електронний монтаж, спецефекти, зйомка окремих епізодів, репетицій тощо 3 допомогою відеотехніки для подальшого повторення чи для прямого переведення на кіноплівку (поки що цей процес, на відміну від простого переведення з кіноплівки на відео, технічно не до кінця відпрацьований i тому важкий i дорогий) стали достатньо поширеними. Більше того, естетика цілої низки кінокартин стала базуватися на відеоефектах.» [9, 129-130]. Як приклад, К. Разлогов наводить фільм Френсіса Копполи «Від усього серця» 1982 року. Зрештою, сам В. Кісін уже свого часу далекоглядно розцінював ті перетворення, що відбувалися у телебаченні з появою відео, не лише як важливі події мистецького, а й загальнокультурного значення. Відкриття у напрямі відеофільму, за пере- 
конанням дослідника, не зможуть залишитися ізольованими від інших мистецтв. Передусім відео матиме вплив загалом на екранну естетику. Також «досвід розвитку відеофільму і в нашій країні, і за кордоном дає право говорити про початок нового етапу розвитку кіномистецтва, про оновлення кіноестетики.» [2, 94].

Виникнення відео на телебаченні стало переламним моментом для розвитку всієї екранної видовищної творчості та телевізійної творчості зокрема. Із появою нових технічних можливостей почали 3'являтися і нові форми й жанри телевізійної творчості. Одним з таких жанрів постає відеофільм. Імовірно, з сучасного погляду цей відносно невеликий за часом період 3 його пошуками й експериментами і може видатися спочатку незначною фазою в історії розвитку телебачення, та слід зауважити, що експерименти і пошуки у сфері телевізійної відеотворчісті передують виходу на новий етап розвитку телебачення — цифровий. I тут усі попередні пошуки і надбання актуалізуються з новою потужною силою. Відеофільм, де відбувалися найбільш напружені шукання засобів нової екранної виразності (у сфері фактури екранного зображення, монтажу, спецефектів тощо), отже, можна цілком закономірно вважати попередником усіх форм і жанрів цифрової епохи. Слід зауважити, що в Україні, незважаючи на певне технічне відставання навіть від Росії, процес оволодіння й застосування відео як потужного виражального засобу не стояв на місці, а рухався зусиллями прогресивних режисерів, операторів, відеоінженерів, художників та інших творчих і технічних працівників телебачення, і результати цієї роботи часто далеко упереджували тогочасні технічні можливості. А ті художні експерименти, що їх представляли творчі групи, які працювали на власному ентузіазмі, в багатьох випадках випереджали час, та часто були неналежно оцінені сучасниками.

\section{Джерела та література:}

1. Вітер В. Віктор Кісін: на шляху до видовища. Кіно-Теamp. № 2, 2011. С. 30-34.

2. Кісін В. Б. Відеофільм. Перші кроки і перспектива. Мистечттво кіно: Республіканський міжвідомчий науковий збірник. Київ: Мистецтво. Вип. 4, 1983. 103 с., с. 82-95.
3. Кісін В. Б. Режисура як мистецтво та професія. Навчальне видання. Київ: Науково-освітній центр «АЕЛС-технологія», 1998. $104 \mathrm{c.}$

4. Косач Ю. А. Кіно- і теледокументалістика: перспективи розвитку. Мистеитво кіно: Респ. міжвід. наук. зб. Київ: Мистецтво. Вип. 5, 1984. 108 с., с. 24-33.

5. Лысенко А. Главный герой / А. Лысенко. Документальный видеофильм: этап становления. Москва: Искусство, 1982. C. $57-72$.

6. Новые аудиовизуальные технологи: Учебное пособие. Москва : Эдиториал УРСС, 2005. 488 с.

7. Одинець О. Український документальний відеофільм. Перші кроки. Науковий вісник Київського начіонального університету театру, кіно і телебачення імені I.К. Карпенка-Карого: 3б. наук. пращь. К., 2010. Вип. 7. 372 с., c. $99-118$.

8. Палій Є. Н. Інженер як співавтор відеофільму. Мистеитво кіно: Pесп. міжвід. наук. зб. - Київ: Мистецтво. Вип. 4, 1983. 103 с., с. 95-99.

9. Разлогов К. «Видеобум»: истоки и перспективы. Телевидение вчера, сегодня, завтра. Вып. 7. Москва: Искусство. 1987. 276 c., с. 126-139.

10. Романовский И. Видеофильм - технология и творчество / И. Романовский. Документальный видеофильм: этап становления. Москва: Искусство, 1982. С. 29-56.

11. Шергова Г. Арсенал выразительных средств / Г. Шергова. Документальный видеофильм: этап становления. Москва: Искусство, 1982. С. 106-126.

\section{References}

1. Viter, V. (2011). Victor Kissin: on the way to the spectacle. Kino-Teatr, 2, pp. 30-34 [in Ukrainian].

2. Kisin, V. B. (1983). Videofilm. First steps and perspective. Mistectvo kino: Respublikanskij mizhvidomchij naukovij zbirnik, 4, pp. 82-95 [in Ukrainian].

3. Kisin, V. B. (1998). Directing as an art and a profession. Educational edition. Kyiv: AELS-Technology [in Ukrainian].

4. Kosach, Y. A. (1984). Film and TV documentary: prospects for development. Mistectvo kino: Respublik. Mizhvid. naukovij zb., 5, pp. 24-33 [in Ukrainian].

5. Lysenko, A. (1982). The main character. Documentary videofilm: the stage of formation. Moscow: Iskusstvo, 57-72 [in Russian].

6. New audiovisual technologists: A training manual. (2005). Moscow: URSS editorial [in Russian].

7. Odinets, O. (2010). Ukrainian documentary videofilm. First steps. Naukovij visnik Kiyivskogo nacionalnogo universitetu teatru, kino i telebachennya imeni I. K. Karpenka-Karogo: Zbirnik naukovih prac. Kyiv, 7, pp. 99-118 [in Ukrainian].

8. Paliy, E. N. (1983). Engineer as co-author of the videofilm. Mistectvo kino: Respublik. mizhvidom. naukovij zb., 4, pp. 95-99 [in Ukrainian].

9. Razlogov, K. (1987). «Videoobum»: sources and perspectives. Television yesterday, today, tomorrow, 7 . Moscow: Iskusstvo, pp. 126-139 [in Russian].

10. Romanovsky, I. (1982). Videofilm - technology and creativity. Documentary videofilm: the stage of formation. Moscow: Iskusstvo, pp. 29-56 [in Russian].

11. Shergova, G. (1982). Arsenal of expressive means. Documentary videofilm: the stage of formation. Moscow: Iskusstvo, pp. 106-126 [in Russian]. 